\title{
ARTICLE
}

\section{"Commitment to Collaboration": What Students Have to Say About the Values Underpinning Partnership Practices}

\author{
*Benjamin Luo ${ }^{a}$, Kelly E. Matthews ${ }^{b}$, and Prasad Chunduria \\ aSchool of Biomedical Sciences, The University of Queensland, Australia \\ ${ }^{b}$ Institute for Teaching \& Learning Innovation, The University of Queensland, Australia
}

Contact: benjaminluo95@gmail.com

ABSTRACT

Students as Partners ( $\mathrm{SaP}$ ) is about students and staff working together in teaching and learning. It is guided by the values of partnership. Knowing how students understand these values, particularly students new to the ideas and language of SaP, would enrich the scholarly conversation about partnership practices. To that end, our study asked students unfamiliar with SaP, "what values and attitudes do you think are necessary for students and academics to work as collaborative partners on teaching and learning?" We captured 173 written responses from students in a biomedical sciences degree program in an Australian university. Thematic analysis revealed four key values: respect, communication, understanding, and responsibility/commitment. We discuss the results through the lens of reciprocity and power, emergent consumerist culture in higher education, and the disciplinary context of science. In conclusion, we encourage dialogue between staff and students to illuminate and affirm the values of partnership that define SaP.

\section{KEYWORDS}

students as partners, student-staff partnerships, values, reciprocity, higher education

Engaging with students as partners (SaP) in learning and teaching is a growing movement in which staff and students develop a working relationship to co-create their educational experiences (Matthews, Cook-Sather, \& Healey, 2018). This movement goes against the traditional role of staff and students, where staff generally direct all aspects of students' learning, from curriculum to learning environment, while students merely follow the directions. Partnerships, on the other hand, are commonly described as "a collaborative, reciprocal process through which all participants have the opportunity to contribute equally, although not necessarily in the same ways, to curricular or pedagogical conceptualisation, decision-making, implementation, investigation, or analysis" (Cook-Sather, Bovill, \& Felten 2014 , p. 6-7). This conception of pedagogical partnerships regards both parties-students and staff-as having unique and valuable insights to offer that can enrich the process and 
outcomes of learning. Where students have engaged as partners in learning and teaching, a range of desirable outcomes have been documented. For example, a review of 65 papers on SaP (Mercer-Mapstone et al., 2017) found that $92 \%$ of papers reported positive outcomes for students and $79 \%$ reported positive outcomes for staff.

These outcomes are similar for both parties and can be roughly grouped into three clusters (Cook-Sather et al., 2014). Firstly, SaP increases engagement. For students, this includes being more motivated in their learning and taking more ownership for their education. For staff, this equates to higher motivation for teaching, research, and participation in partnerships. Secondly, SaP increases awareness of learning and teaching habits to both parties. Thirdly, SaP leads to improvements in the overall educational process. Healey, Flint, and Harrington (2014) claim that by valuing the individual contributions of students, alumni, and staff, partnerships develop a better sense of community within the university: "a shared learning community" (p. 20). Yet, engaging in $\mathrm{SaP}$ is not easy or straight-forward. Bovill, Cook-Sather, Felten, Millard, \& Moore-Cherry (2016) discuss common challenges for students and staff, challenges largely due to a clash between SaP values and the cultural norms of our long-standing educational institutions.

Given the potential of SaP, it is useful to examine the values underpinning partnership practices. More than a recipe to follow, SaP has been discussed as the creative embodiment of partnership values (Matthews, 2017). Thus, the ideological framework for $\mathrm{SaP}$ is ultimately grounded in a set of values (Matthews, Dwyer, Hine, \& Turner, 2018). As explicitly stated by the Quality Assurance Agency (QAA, 2012) for UK, "partnership working is based on the values of: openness; trust and honesty; agreed shared goals and values; and regular communication between the partners" (p. 5). Key academics in the field also restate the importance of these principles with the addition of others such as reciprocity, respect, and responsibility (Healey et al., 2014; Cook-Sather et al., 2014). We believe this continual reflection of and reference to shared values cultivates genuine SaP praxis (Matthews, 2017). This process of sharing meaning grounds everyone in the mutual goals of improving learning and teaching, and helps define the specific practices of curriculum co-creation (Chemi \& Krogh, 2017).

Without these guiding values, the transformative potential of partnerships may be dampened. For example, Dwyer (2018), writing as a student, raises concerns about SaP being appropriated for neoliberal purposes in ways that further exacerbate a culture of competition amongst students. Cook-Sather and Felten (2017) highlight how dehumanising language (e.g., referring to student as customers or staff as service providers) reduces education to a mere transaction of commodities and diminishes the centrality of human relationships to learning. Indeed, recent research highlights that some institutional leaders view SaP from a neoliberal ethic (Matthews, Dwyer, Russell, \& Enright, 2018), which hinders the ability of learner-teacher partnerships to move universities toward egalitarian learning communities (Matthews, Cook-Sather, \& Healey, 2018). As scholars-including studentsarticulate values that can or should form the basis of partnership, we want to further the conversation by exploring the values that students with little experience in SaP practices perceive to be important.

We, as a student (Luo) and two academics (Chunduri and Matthews), draw upon a dataset of students' perceptions about SaP gathered from a student-led honours research project (Matthews, Groenendijk, \& Chunduri, 2017). Findings from the quantitative data revealed that most students who participated in the survey, but not all of them, wanted to 
be more involved in SaP practices. In this current article, we present findings from the qualitative data. Luo, the first author of this article, initially led the analysis through a paid partnership project. Eventually, he took the lead role for this article which included framing and drafting the discussion after reading the literature. This shift in itself, from being a student participating in scholarly inquiry to a student taking a collaborative role in partnership typically reserved for staff (Matthews, 2018), represents an example of the transformative journey toward genuine SaP praxis through knowledge co-creation.

\section{PURPOSE AND CONTRIBUTION}

Our purpose is to further the conversation about the values informing partnership practices. In particular, we wanted to investigate how students who are not familiar with SaP perceived these values. Hence, similar to Marquis, Jayaratnam, Mishra, and Rybkina (2018), and extending from the sibling study of this work (Matthews et al., 2017), we explore the perspectives of a large body of students who have mostly not engaged in explicit partnership. A motivating rationale for our study was the acknowledgement that engagement in SaP is limited to a few, select students (Mercer-Mapstone et al., 2017). Because the growth of SaP will inevitably engage students who are not familiar with the principles of $\mathrm{SaP}$, we want to ensure the values of partnership remain at the forefront of new practices. Hence, we would like to bring the perspectives of these students into the SaP conversation.

Our intended contribution is to highlight the relationship between how students consider the values of partnership and current discussions of values in the scholarly literature on SaP. By doing so, we can clarify any misconceptions held by those unfamiliar with partnership and identify other key discussion points to further dialogue. This will ensure that as SaP grows, it stays grounded in a mutually agreed-upon set of values.

\section{METHODS}

We used an online mixed methods survey to investigate students' attitudes towards SaP. This current study examined the qualitative data, specifically student responses to the following question: What values and attitudes do you think are necessary for students and academics to work as collaborative partners on teaching and learning in degree programs?

Initially, the question was worded to include the term "Students as Partners." However, when the initial survey was piloted with four undergraduate students unfamiliar with the language of SaP, they expressed confusion and uncertainty. The language of "Students as Partners" or "student-academic partnership" or "partnership" alone was too unknown to be effective in a survey. Hence, the wording was revised to express the intended meaning to make sense to students unfamiliar with SaP.

\section{Participants}

The participants of this survey were students at The University of Queensland studying for a degree in either a Bachelor of Science or a Bachelor of Biomedical Science. The overall survey response rate was $24 \%$ (289 students out of 1208), but only $14 \%$ responded to the open-ended question (172 students out of 1208). Of those that responded to the open-ended question, $70 \%$ were women. Furthermore, $13 \%$ were first-year students, $33 \%$ were second-year, $42 \%$ were third-year, $9 \%$ were fourth-year, and $2 \%$ were others. 
These participants had limited exposure to SaP as shown by the quantitative results of our sibling study (Matthews et al., 2017). When asked about how often they participated in a range of different SaP practices (e.g., developing assessment criteria, co-designing course material, being a student representative on a university committee), the vast majority of respondents (over $80 \%$ ) replied "not at all" or "a little." Hence, their responses would reflect how those without SaP involvement might perceive the values of partnership between students and staff.

\section{Analysis}

We used thematic analysis, as outlined by Braun and Clarke (2006), to interpret student responses. Thematic analysis is a widely used technique that seeks out patterns of meaning within qualitative data (Attride-Stirling, 2001). These patterns become the themes, which highlight the important elements of a phenomenon. Specifically, we used an inductive approach whereby data was processed without attempting to fit it within a pre-existing theory (Braun \& Clark 2006). Instead, we aimed to derive all themes from the data alone so our results would more accurately reflect the students' sentiments.

Firstly, all the data was de-identified and the quantitative data generated from the survey instrument was removed so that only the answers to the open-ended questions of the survey remained. This was presented to Luo, who familiarised himself with the dataset. Importantly, having not read any papers about engaging students in partnership, his initial analysis and coding were not immediately influenced by the academic literature (he would eventually read the literature and engage in further dialogue with his co-authors once the themes had emerged from the data). After familiarising himself with the dataset, Luo then organised the responses into broad themes. Using these preliminary themes, he coded the responses to test how well the themes mapped on to the dataset.

After two iterative rounds of refining the themes and discussions amongst the coauthors, a working coding framework was produced. It consisted of 6 themes: respect, initiating communication, the nature of communication, understanding, open-mindedness, and responsibility/commitment. Furthermore, responses were coded based on whether the commentary was directed at students, academics, or both. In other words, were values discussed as something that applied to students and staff separately or together? Data was coded as "non-directed" if the response was not directed at a specific party.

Then, a coding framework was formalised. Together, all three researchers discussed and agreed on the appropriate definition for each theme. This was followed by an independent coding process by Chunduri and Matthews, using the framework, and then further discussion amongst the researchers. Any differences in coding were reviewed and agreed upon. At this point, we combined two themes, "initiating communications" and "nature of communication," to form communication. Similarly, we combined "understanding" and "open-mindedness" to form one theme, understanding. The resulting final coding framework is provided in Table 1. 
Table 1. Coding framework derived from student responses

\begin{tabular}{|l|l|}
\hline THEME & DESCRIPTION \\
\hline Respect & Respecting the other person \\
\hline Understanding & $\begin{array}{l}\text { Initiating communication with each other } \\
\text { Improving some aspect of communication (e.g., clarity, } \\
\text { honesty) }\end{array}$ \\
\hline Responsibility/commitment & $\begin{array}{l}\text { Being more understanding of each other's perspective } \\
\text { Being willing to consider different ideas } \\
\text { Being willing to change the course structure }\end{array}$ \\
& $\begin{array}{l}\text { Being responsible/committed to the goal of partnership } \\
\text { Being responsible/committed to improving the learning } \\
\text { process } \\
\text { partnership }\end{array}$ \\
\hline Other & Any responses which did not fit into the categories above \\
\hline
\end{tabular}

\section{LIMITATIONS}

We acknowledge that all studies have limitations. There are four particular limitations that we want to discuss. Firstly, this is a one-off study in one context at a specific point in time. While this is a common approach in exploratory studies, we should take care when generalising the results because context shapes SaP practices (Healey \& Healey, 2018). Secondly, at $14 \%$, the response rate was low, again prompting us to caution readers against making broad generalisations. Instead, we urge readers to draw on these findings to guide practice and further research. Thirdly, while we sought to capture student perspectives on a large scale using a one-way survey instrument, we acknowledge that dialogue with students through interviews or focus groups would have enriched the study. Finally, our views as a medical student with a background in psychology (Luo), a biomedical sciences lecturer teaching large classes (Chunduri), and an academic in a centralised teaching and learning unit (Matthews), may have influenced how we interpreted the words of students. While we spent time questioning our assumptions and reflecting on our beliefs through ongoing professional conversations, we acknowledge our bias. To this end, we are making the dataset available for others to draw upon in their own research (Luo, Matthews, \& Chunduri, 2018).

\section{RESULTS}

Out of the 172 responses, only one said he/she did not believe "academics and students should be working this closely together." This suggests that most respondents were accepting of the idea of SaP but not unanimously-an important reminder to avoid viewing students as a single entity. Of the remaining 171 responses, respect was the most common value students viewed as necessary for collaboration, followed by communication, understanding, and responsibility/commitment. Table 2 shows direct quotes from the student responses that exemplify each of the four themes. Figure 1 shows the percentages for each theme. Student responses varied from full sentences to sentence fragments and this is reflected in the quotes below. 
Table 2. Examples of student responses by theme

\begin{tabular}{|c|c|}
\hline THEME & EXAMPLES OF QUOTES FROM STUDENTS \\
\hline Respect & $\begin{array}{l}\text { For students and academics to work together they must respect } \\
\text { one another } \\
\text { Mutual respect, especially academics treating students like } \\
\text { adults } \\
\text { Both students and academics should respect each other's time } \\
\text { constraints }\end{array}$ \\
\hline Communication & $\begin{array}{l}\text { Students need to be more willing to talk to academics } \\
\text { Academics need to be more welcoming in their approach to } \\
\text { talking to students } \\
\text { I think not enough students participate in the course evaluation } \\
\text { survey }\end{array}$ \\
\hline Understanding & $\begin{array}{l}\text { On the academics' side, they must understand that times have } \\
\text { changed and that education is now different } \\
\text { Students should also be mindful of the hard work academics } \\
\text { have put in } \\
\text { Students have many responsibilities outside of a particular } \\
\text { course/academic responsibility e.g. work } \\
\text { Acceptance that something isn't working - especially for courses } \\
\text { that have been running for a long time and need significant } \\
\text { changes }\end{array}$ \\
\hline $\begin{array}{l}\text { Responsibility/ } \\
\text { commitment }\end{array}$ & $\begin{array}{l}\text { Commitment to collaboration } \\
\text { Having a genuine desire to improve course content and student } \\
\text { outcomes } \\
\text { It will take deep commitment on both sides to change the } \\
\text { culture }\end{array}$ \\
\hline Other & Self-appraisal and critical thinking regarding student well being \\
\hline
\end{tabular}


Figure 1. Responses by theme, shown as percentages of the 172 responses given

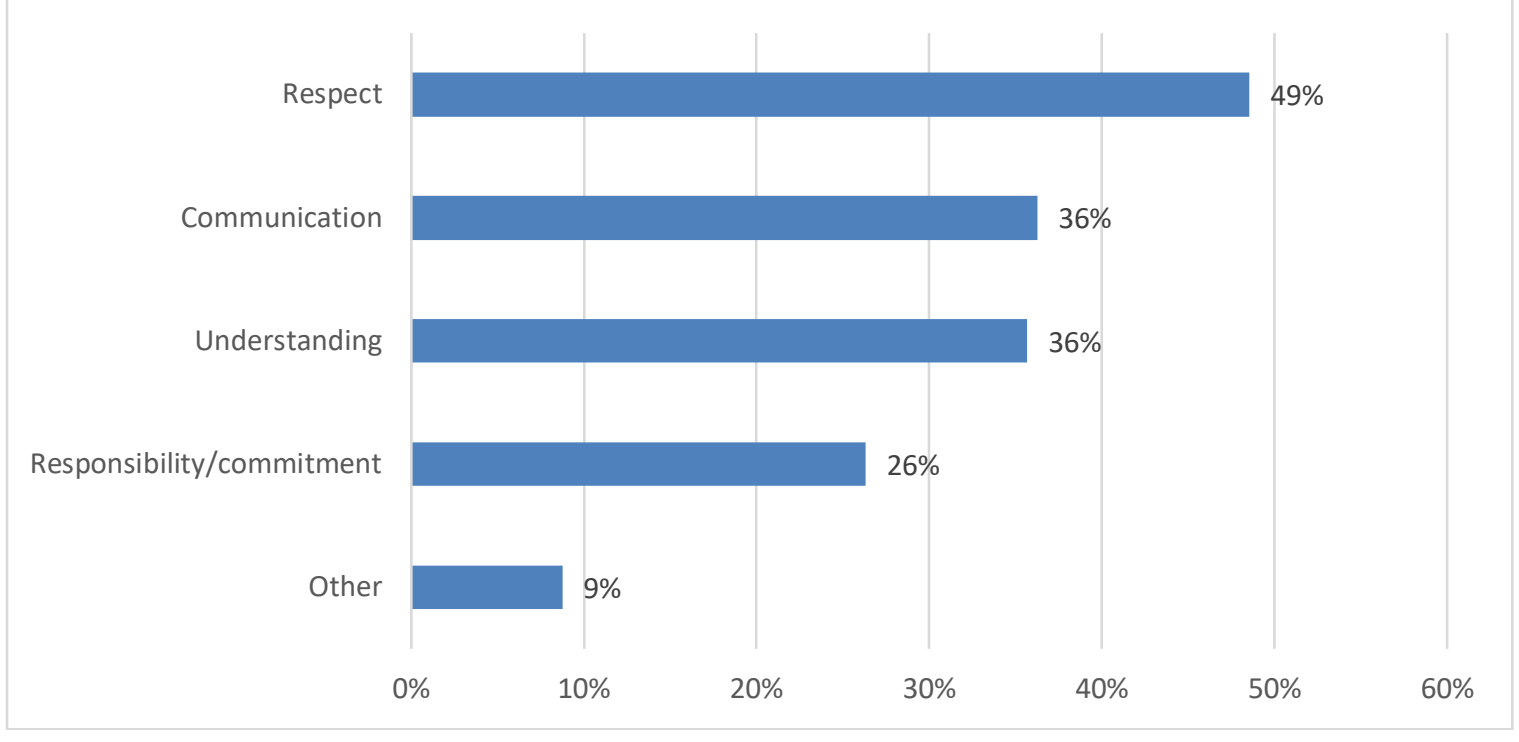

Following the thematic analysis that generated the main themes, we re-read the student responses, this time to code whether a response/theme was directed towards students, academics, or both parties (see Figure 2). Our analysis excluded responses which were vague or not directed at any party. Also, if a response was explicitly directed to both parties but leaned more heavily towards one party, it was counted under the party (students or academics) as well as under "mutual." An example of one such response, "mutual respect is important but academics need to not belittle students," would be counted as directed at academics and at both parties. This allowed us to capture more nuance in the data and explores a latent sense of reciprocity across the responses.

Figure 2. Responses by theme, distributed by the focus of responsibility for enacting each theme (i.e. students, academics or both)

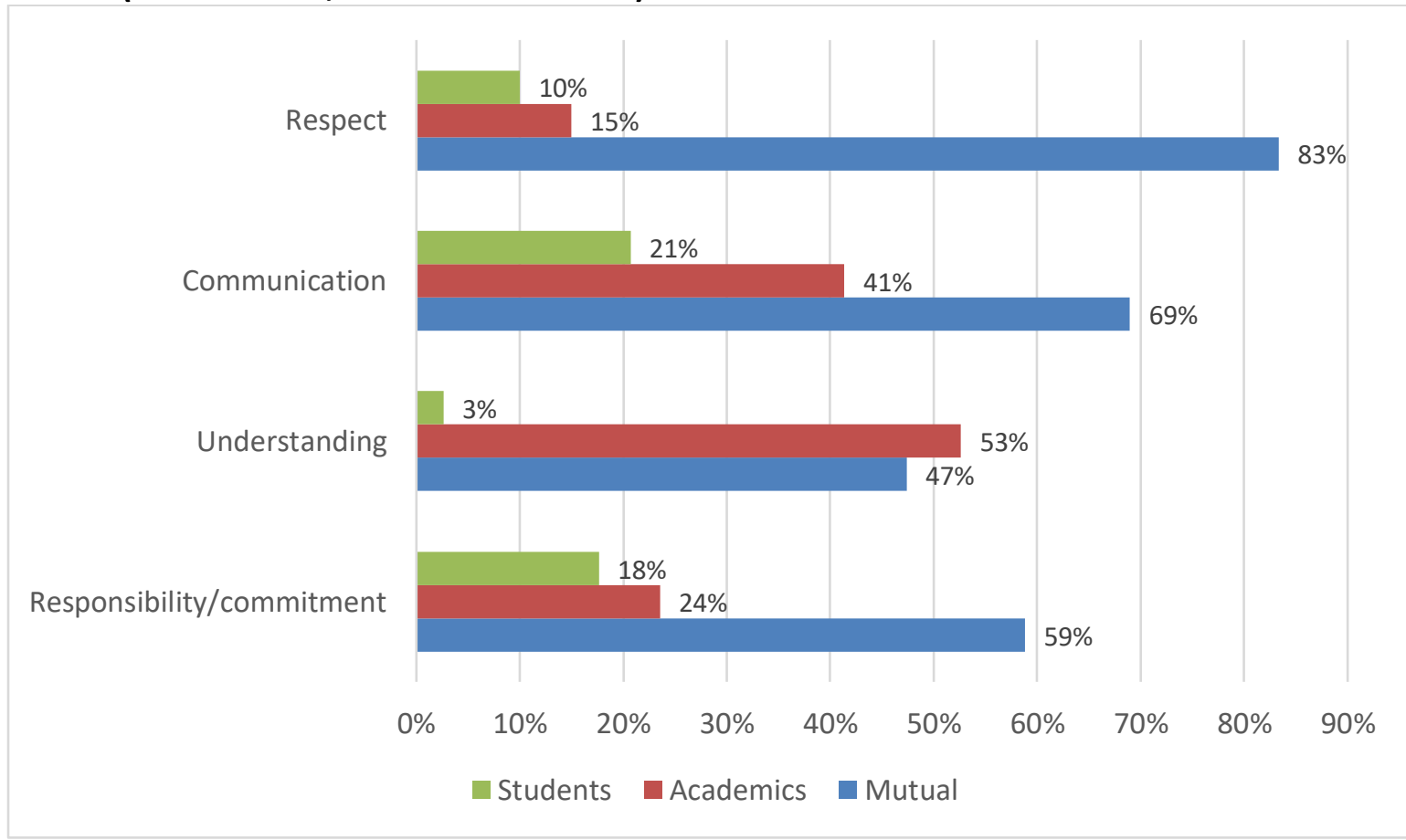


Most students believed that both parties were responsible for upholding these values. Of all the values, respect had the highest percentage of students agreeing that it was a mutual value to uphold; $83 \%$ of the responses that mentioned respect said that both students and academics needed to respect each other. On the other hand, when it came to understanding, more students felt that there was a heavier responsibility for academics here compared to students ( $53 \%$ vs. $3 \%$ respectively).

Furthermore, there is an indication that students in the study viewed these values differently when enacted by students or by academics. Table 3 and 4 show quotes from students that exemplify this difference.

With regards to respect, participants acknowledged the importance of mutual respect. Yet, there was a sense that respect was earned and how students earned this respect differed from how academics did. Notions of maturity and acting like adults surfaced for students, which had to be met by academics willing to treat students like adults.

In terms of communication, students in the study typically perceived that both students and academics should try to initiate more communication with each other. However, the participants signalled an additional need for academics to be clearer, friendlier, and more approachable in their communication.

Table 3. Description of how students could enact these themes

\begin{tabular}{|c|c|c|}
\hline THEME & $\begin{array}{l}\text { HOW STUDENTS COULD } \\
\text { ENACT THIS THEME }\end{array}$ & STUDENT QUOTES \\
\hline Respect & $\begin{array}{l}\text { Respecting the experience of } \\
\text { academics } \\
\text { Acting in a way that is } \\
\text { deserving of respect (e.g., } \\
\text { not talking during lectures) }\end{array}$ & $\begin{array}{l}\text { Students must respect that academics } \\
\text { are experts in their respective fields } \\
\text { It's important for there to be maturity } \\
\text { on the student's behalf }\end{array}$ \\
\hline Communication & $\begin{array}{l}\text { Initiating talks with } \\
\text { academics } \\
\text { Giving more feedback and } \\
\text { asking more questions }\end{array}$ & $\begin{array}{l}\text { Students would need to be proactive in } \\
\text { approaching their mentors } \\
\text { It is extremely important to receive } \\
\text { feedback from students in order to } \\
\text { make improvements }\end{array}$ \\
\hline Understanding & Being more open to criticism & $\begin{array}{l}\text { Students in particular should welcome } \\
\text { criticism and learn as much as } \\
\text { possible from any academic } \\
\text { interactions }\end{array}$ \\
\hline $\begin{array}{l}\text { Responsibility/ } \\
\text { commitment }\end{array}$ & $\begin{array}{l}\text { Being responsible for filling } \\
\text { out Student Evaluation of } \\
\text { Courses and Teacher } \\
\text { (SECaT) evaluations } \\
\text { Being willing to put in work } \\
\text { for better learning } \\
\text { outcomes }\end{array}$ & $\begin{array}{l}\text { SECaTs are great because we can let } \\
\text { academics know what we like and } \\
\text { don't like. I think these should be } \\
\text { compulsory } \\
\text { A keen interest in learning from } \\
\text { students }\end{array}$ \\
\hline
\end{tabular}


Table 4. Description of how academics could enact these themes

\begin{tabular}{|c|c|c|}
\hline THEME & $\begin{array}{l}\text { HOW ACADEMICS COULD } \\
\text { ENACT THIS THEME }\end{array}$ & STUDENT QUOTES \\
\hline Respect & $\begin{array}{l}\text { Treating students as equals } \\
\text { Not being condescending or } \\
\text { belittling }\end{array}$ & $\begin{array}{l}\text { Academics should treat students as } \\
\text { adults } \\
\text { I was very disappointed because } \\
\text { many of the lecturers left me } \\
\text { feeling stupid and struggling when } \\
\text { I would reach out for help }\end{array}$ \\
\hline Communication & $\begin{array}{l}\text { Initiating talks with students } \\
\text { Being more approachable } \\
\text { Clearer communication }\end{array}$ & $\begin{array}{l}\text { What is necessary is the ability of } \\
\text { academics to communicate } \\
\text { effectively } \\
\text { I think academics should remind } \\
\text { students that they are there to } \\
\text { help and do not mind being asked }\end{array}$ \\
\hline Understanding & $\begin{array}{l}\text { Understanding that students } \\
\text { have other commitments } \\
\text { Understanding that students } \\
\text { have less experience and } \\
\text { knowledge than them } \\
\text { Being willing to change their } \\
\text { way of teaching }\end{array}$ & $\begin{array}{l}\text { There does not appear to be much } \\
\text { leniency for individuals who may } \\
\text { have to work to support } \\
\text { themselves } \\
\text { Academics need to be more open } \\
\text { and understand students are not } \\
\text { perfect and have less experience }\end{array}$ \\
\hline $\begin{array}{l}\text { Responsibility/ } \\
\text { commitment }\end{array}$ & $\begin{array}{l}\text { Being responsible for changing } \\
\text { the course according to the } \\
\text { students' needs } \\
\text { Being committed to student } \\
\text { outcomes }\end{array}$ & $\begin{array}{l}\text { Many course co-ordinators are either } \\
\text { too lazy/think there is no room for } \\
\text { improvement, so the course never } \\
\text { undergoes change } \\
\text { Academics need to be willing to help } \\
\text { grow students' knowledge and } \\
\text { skills in the field of collaboration }\end{array}$ \\
\hline
\end{tabular}

For the theme of understanding, there was a stronger focus on academics understanding the challenges of students. Furthermore, students wanted this understanding to translate into actual changes in their ways of teaching. There was less focus on students understanding the challenges academics might face.

The responsibility and commitment of academics and students were also perceived to be different. For students, participants saw a responsibility to give feedback to the academics on how to improve the courses. For academics, there was a corresponding responsibility to change these courses based on student feedback. However, survey respondents believed that both parties should be passionate and committed to improving the educational process.

\section{DISCUSSION}

We wanted to understand what values and attitudes students thought were important to student-academic partnerships in learning and teaching. The students who participated in the study had little familiarity or experience with SaP pedagogies. Hence, they provide a new perspective to the literature, which to date has mostly focused on 
people who already have experience with SaP (Mercer-Mapstone et al., 2017). Understanding the values that matter to students-in their own words-helps conceptualise how students might come to the idea of co-creating education through partnership.

Overall, we found four overlapping yet distinct themes regarding the values that students perceive to be important for partnerships in teaching and learning in degree programs: respect, communication, understanding, and responsibility. These values can be found throughout various key papers in the SaP literature (Cook-Sather et al., 2014; Healey et al., 2014). Guided by Luo's personal experience as a student, Matthews' knowledge of the literature, and Chunduri's practical experience of bringing partnership practices to large classes in the sciences, we discuss three predominant topics within the findings and their implications for SaP theorising and practice.

\section{Recognising the importance of reciprocity and the role of power}

Reciprocity is seen as a fundamental aspect of SaP (Cates, Madigan, \& Reitenauer, 2018; Cook-Sather \& Felten, 2017; Cook-Sather et al., 2014; Matthews, 2017; MercerMapstone et al., 2017). It is defined as the process whereby all involved are equally contributing their unique perspectives, insights, and other forms of participation through partnership. Since academics and students have different perspectives, occupy differing positions of power, and have different skills, what constitutes equal contributions will vary from practice to practice (Cook-Sather et al., 2014). However, at a basic level, reciprocity requires students to take some of the perspectives and responsibilities of staff, and vice versa. For example, if students and academics were co-creating assessments, students might consider the difficulties that staff face when marking hundreds of papers. Likewise, staff might consider the difficulties of students who balance full-time study with a job.

Most students viewed the values of respect, communication, understanding, and responsibility as mutual values for both students and academics. While few students used the word "reciprocity," it was evident in responses that talked about values being enacted by both students and academics and how shared responsibility was beneficial for both. One example that reveals, on a latent level, the primacy of reciprocity is:

Academics need to be willing to take responsibility for their mistakes made and accommodate the students' needs when this occurs. Students need to respect the academics, listening and participating in class and be more willing to ask questions and discuss topics.

As SaP hopes to engage the broader community of students, it is promising that many of them already agree with the fundamental principle of reciprocity.

Particular words alluded to reciprocity more specifically, including "equal" and "mutual." Different individuals perceive "equal" contributions differently. Thus, it is essential to discuss what is meant by "equal contribution," particularly in classroom SaP practices where power dynamics are always at play. The word "mutual" was typically connected to respect, signalling the importance of shared, two-way respect between students and academics. However, traditional power dynamics and culturally situated understandings of values were evident. For example, some students explained that mutual respect requires students to act in a way that is deserving of respect. In such responses, 
there is an inferred onus on students to earn respect, suggesting academics do not need to work as hard to earn the respect of students.

Through these students' responses, our interpretative process of analysis, and our own discussions across student-academic perspectives, we identified the fundamental role of dialogue about the values of partnership, especially two-way conversations that can reveal our assumed understanding of values, which might be endorsed (e.g., respect) but rarely discussed in classroom settings in the context of learning and teaching. This implies that practising partnership in classrooms where students are unfamiliar with SaP should start with unpacking the values central to partnership. Creating space for dialogue in the classroom to explicitly define what is meant by these value terms would be beneficial. Potentially, the value terms, definitions, and illuminating quotes from students presented in the results section of this paper can become a resource enabling students and academics to co-create an understanding of the values that matter to them.

\section{Deferring responsibility as customers}

While most responses suggested that students and academics should be working in a reciprocal manner, this was not universally evident across the data set. A significant minority of students believed that academics should take principal responsibility for directing the educational process, particularly when it came to improving courses. For instance: "academics should design assessment that is designed to enhance learning rather than streamline marking. Students should let academics know when assessment is not benefiting their learning." This infers a passive role for students whereby they give their opinion, often through an anonymous evaluation survey, without the dialogue or reciprocity underpinning genuine SaP practices. However, this preconception of SaP as a one-way transmission of de-personalised feedback is understandable when viewed from a business orientation or neoliberal ethic.

The attitude that academics are primarily responsible for the students' perceived quality of education is characteristic of the "students-as-consumers" model. This model came about as the increased privatisation of universities introduced market forces to education (McMillan \& Cheney, 1996; Hemsley-Brown \& Oplatka, 2006; Baldwin \& James, 2000). Universities were consequently redefined as service providers, with education becoming the product and students the consumers. Like a standard business, universities must place the utmost importance on satisfying the demands of the students or risk losing these customers to competing universities (Furedi, 2010). This developed the culture of students expecting universities to take sole responsibility of improving courses, to the point that the idea of a mutual collaboration between students and academics seems foreign to current higher education students (McPherson \& Heggie, 2015).

A consequence of this mentality is that students have less empathy for teachers. Empathy is defined by the ability to bridge the gap between one's self experience and others' experience (Hodges \& Klein, 2001). In the broader literature of psychology, it has been linked to increased co-operation (Decety, Bartal, Uzefovsky, \& Knafo-Noam, 2015) and reduced prejudices (Tarrant, Dazely, \& Cottom, 2009), both of which are important to partnerships. Ntem and Cook-Sather (2018) illuminate the role of empathy in engendering trust in pedagogical partnership. Yet, as universities become more dependent on student evaluations as a measure of teaching quality, students have gotten a new form of power. The power of student evaluations over academics tends to reduce empathy as students 
become more removed from academics and less motivated to understand their struggles (van Kleef et al., 2008; Hogeveen, Inzlicht, \& Obhi, 2014). Some of the responses in our study demonstrate this lack of empathy towards academics. For example, there was an observable emphasis placed on academics needing to understand students with less evidence that students perceived they needed to empathise with academics. This may consequently damage the student-teacher relationship, something which is central to learning and pedagogical partnership.

Ultimately, SaP is responding to the problems of the student-as-consumer model. SaP asks students to take shared responsibility in their education by entering a reciprocal partnership with academics and engaging in power sharing through dialogue (Matthews, 2017). Our results indicate that for some students, this may conflict with the usual, or even unconscious, expectations for academics to do most of the work. It also suggests that we should attempt to get students to empathise more with academics during SaP. In practice, this implies that when academics bring SaP into classrooms they might model empathy by asking about students' lives and sharing information about their own lives. Similarly, approaches that disrupt the one-way evaluative survey system where students complete feedback surveys for staff might be considered. For example, Bovill (2011) outlines a model where students evaluate the class while also evaluating their own involvement in self- and peer-learning, through self-reflection.

\section{SaP in the context of science}

In interpreting our findings, we consider the disciplinary context shaping the perceptions of students in our study. As Healey and Healey (2018) argue, SaP practices are always context-dependent. The implicit cultural norms and values of a discipline influence the educational practices within that discipline (Yaakobi \& Sharan, 1985; Trowler \& Cooper, 2002; Matthews, 2014). In the sciences, objectivity is privileged along with the search for a universal truth. That epistemological orientation is at odds with theorisations of SaP as human, messy, and a relational praxis (Matthews et al., in press). Therefore, as our responses come from a cohort of science students, we consider the potential implications of SaP's value-based practices being enacted in the sciences and other disciplines.

Science operates within a framework of knowledge derived empirically and detached from subjective experience (Witz, 1996). This influences the pedagogical beliefs of science teachers, with almost $50 \%$ of science educators in a study claiming that science education should be "value free" (Wellcome Trust, 2001). Many science curricula omit relevant discussions about the ethical and societal implications of science that reveal the subjectivity of the discipline (Chowdhury, 2016). Furthermore, teachers have anecdotally expressed concerns about introducing subjective discussions out of fear students will bring in personal opinions (Wellcome Trust, 2001). The lack of value-based discussion within science courses juxtaposes the value-based ethos of SaP and our suggestions above for creating space within classrooms for dialogue between academics and students.

Because many science teachers do not have the confidence, skill, or experience to engage in discussions that draw on individual beliefs and different interpretations of reality (Ratcliffe, Harris, \& McWhirter, 2004; Harris \& Ratcliffe, 2005; Ratcliffe, 2007), classroom pedagogy in the sciences tends to stick to transmitting the canon of scientific knowledge. This privileges knowledge expertise where academics hold more authoritative positions (Bartholomew, Osborne, \& Ratcliffe, 2004). In contrast, SaP undermines this traditional 
classroom approach by asserting students have expertise to offer in shaping pedagogical practices (Cook-Sather et al., 2014; Healey et al., 2014). The students in our study come from a disciplinary context where the science teaching typically aligns with this traditional stance. Furthermore, they have limited experience of engaging in SaP practices. In this light, the significant minority of students revealing perceptions that academics should take greater responsibility becomes more understandable. Indeed, Bunce, Baird, and Jones (2017) found that students in the sciences had higher rates of passive, consumer-orientated approaches in universities compared to other disciplines.

Thus, the nature of SaP practices being grounded in subjective values might be difficult for both academics and students in the sciences to understand or accept. Future research could investigate how values-based SaP practices are being introduced and enacted in the science classrooms. In addition, comparative studies exploring the influence of epistemological orientations across disciplines could enrich our collective understanding of SaP. These could elucidate how to best introduce and include SaP within the varying cultures of different disciplines with implications for enhancing learning and teaching.

\section{CONCLUSION}

Enacting the values of partnership defines genuine SaP practices. Together, as student and academic co-authors, we contribute to the SaP conversation by analysing the perceptions of students unfamiliar with SaP to understand what values matter to them. Overall, our findings affirmed that the students in our study identify similar values to those of SaP scholars. However, we found a significant minority who showed a lack of empathy for academics and expressed passive, customer-orientated beliefs. Making sense of our results through the lens of reciprocity, students as customers, empathy, and the disciplinary context of science, we argue that dialogue about partnership values in classrooms are a vital first step toward genuine partnership praxis. We encourage SaP practitioners to employ our findings (e.g., the values that emerged from the students and/or their quotes in their own words) as a conversation prompt for dialogue about learning and teaching relationships in the curriculum. Furthermore, we suggest further research that explores the epistemological role of disciplines in SaP practices. Ultimately, we cannot take our understanding of values for granted as they form the basis for genuine SaP practices.

We note that ethics approval for this study has been obtained from our institutional human ethics review committee (approval number 2016000441).

\section{ACKNOWLEDGEMENTS}

We thank the students who participated in the study as well as Lauren Groenendijk who collected the data. We are also grateful to Jacinta Conroy for her support and perceptive feedback during the writing of the manuscript.

\section{NOTES ON CONTRIBUTORS}

Benjamin Luo is a second-year medical student at The University of Queensland.

Kelly E. Matthews is an associate professor in higher education at The University of Queensland, and an Australian Learning and Teaching Fellow. 
Prasad Chunduri is a lecturer in the School of Biomedical Sciences at The University of Queensland.

\section{REFERENCES}

Attride-Stirling, J. (2001). Thematic networks: An analytic tool for qualitative research. Qualitative Research, 1(3), 385-405. https://doi.org/10.1177/146879410100100307

Baldwin, G., \& James, R. (2000). The market in Australian higher education and the concept of student as informed consumer. Journal of Higher Education Policy and Management, 22(2), 139-148. https://doi.org/10.1080/713678146

Bartholomew, H., Osborne, J., \& Ratcliffe, M. (2004). Teaching students "ideas-aboutscience": Five dimensions of effective practice. Science Education, 88(5), 655-682. https://doi.org/10.1002/sce.10136

Bovill, C. (2011). Sharing responsibility for learning through formative evaluation: Moving to evaluation as learning. Practice and Evidence of the Scholarship of Teaching and Learning in Higher Education, 6(2), 96-109. Retrieved from: http://community.dur.ac.uk/pestlhe.learning/index.php/pestlhe/article/view/53

Bovill, C., Cook-Sather, A., Felten, P., Millard, L., \& Moore-Cherry, N. (2016). Addressing potential challenges in co-creating learning and teaching: Overcoming resistance, navigating institutional norms and ensuring inclusivity in student-staff partnerships. Higher Education, 71(2), 195-208. https://doi.org/10.1007/s10734-015$\underline{9896-4}$

Braun, V. \& Clarke, V. (2006) Using thematic analysis in psychology. Qualitative Research in Psychology, 3(2), 77-101. https://doi.org/10.1191/1478088706qp063oa

Bunce, L., Baird, A., \& Jones, S. (2017). The student-as-consumer approach in higher education and its effects on academic performance. Studies in Higher Education, 42(11), 1958-1978. https://doi.org/10.1080/03075079.2015.1127908

Cates, R., Madigan, M., \& Reitenauer, V. (2018). 'Locations of Possibility': Critical perspectives on partnership. International Journal for Students as Partners, 2(1), 3346. https://doi.org/10.15173/ijsap.v2i1.3341

Chemi, T., \& Krogh, L. (2017). Co-creation in higher education: Students and educators preparing creatively and collaboratively to the challenge of the future. Rotterdam, The Netherlands: Sense Publishers.

Chowdhury, M. (2016). Gifted education in science and chemistry: Perspectives and insights into teaching, pedagogies, assessments, and psychosocial skills development. Journal for the Education of Gifted Young Scientists, 4(1), 53-66. https://doi.org/10.17478/jegys.2018116581

Cook-Sather, A., Bovill, C., \& Felten, P. (2014). Engaging students as partners in teaching and learning: A guide for faculty. San Francisco: Jossey-Bass.

Cook-Sather, A., \& Felten, P. (2017). Ethics of academic leadership: Guiding learning and teaching. In F. Su, \& M. Wood (Eds.), Cosmopolitan perspectives on academic leadership in higher education (pp. 175-191). London: Bloomsbury Academic.

Decety, J., Bartal, I., Uzefovsky, F., \& Knafo-Noam, A. (2015). Empathy as a driver of prosocial behaviour: Highly conserved neurobehavioural mechanisms across 
species. Philosophical Transactions of the Royal Society B: Biological

Sciences, 371(1686). https://doi.org/10.1098/rstb.2015.0077

Dwyer, A. (2018). Toward the formation of genuine partnership spaces. International Journal for Students as Partners, 2(1), 11-15. https://doi.org/10.15173/ijsap.v2i1.3503

Furedi, F. (2010). Introduction to the marketisation of higher education and the student as consumer. In M. Molesworth, R. Scullion, \& E. Nixon (Eds.). The Marketisation of Higher Education and the Student as Consumer (pp. 1-8). New York: Routledge. Retrieved from https://network23.org/freeunisheff/files/2015/07/Mike-MolesworthRichard-Scullion-Elizabeth-Nixon-The-Marketisation-of-Higher-Education-and-theStudent-as-Consumer-book.pdf

Harris, R., \& Ratcliffe, M. (2005). Socio-scientific issues and the quality of exploratory talk what can be learned from schools involved in a 'collapsed day' project? The Curriculum Journal, 16(4), 439-453. https://doi.org/10.1080/09585170500384396

Healey, M., \& Healey, R. (2018). 'It depends': Exploring the context-dependent nature of students as partners practices and policies. International Journal for Students as Partners, 2(1), 1-10. https://doi.org/10.15173/ijsap.v2i1.3472

Healey, M., Flint, A., \& Harrington, K. (2014). Engagement through partnership: Students as partners in learning and teaching in higher education. York: Higher Education Academy. Retrieved from: https://www.heacademy.ac.uk/knowledgehub/engagement-through-partnership-students-partners-learning-and-teachinghigher

Hemsley-Brown, J., \& Oplatka, I. (2006). Universities in a competitive global marketplace: a systematic review of the literature on higher education marketing. International Journal of Public Sector Management, 19(4), 316-338. https://doi.org/10.1108/09513550610669176

Hodges, S., \& Klein, K. (2001). Regulating the costs of empathy: The price of being human. Journal of Socio-Economics, 30(5), 437-452. https://doi.org/10.1016/s10535357(01)00112-3

Hogeveen, J., Inzlicht, M., \& Obhi, S. S. (2014). Power changes how the brain responds to others. Journal of Experimental Psychology: General, 143(2), 755-762. https://doi.org/10.1037/a0033477

Luo, B., Matthews, K. E., \& Chunduri, P. (2018). "Commitment to collaboration": What students have to say about the values underpinning partnership practices: Dataset. Brisbane: University of Queensland. https://doi.org/10.14264/uql.2018.527

Marquis, E., Jayaratnam, A., Mishra, A., \& Rybkina, K. (2018). "I feel like some students are better connected": Students' perspectives on applying for extracurricular partnership opportunities. International Journal for Students as Partners, 2(1), 64-81. https://doi.org/10.15173/ijsap.v2i1.3300

Matthews, K. E. (2014). Students' perspectives on quantitative skills in an undergraduate science curriculum: A mixed methods study of the experienced curriculum (Doctoral dissertation). School of Education, The University of Queensland. https://doi.org/10.14264/uql.2015.87

Matthews, K. E. (2017). Five Propositions for genuine students as partners practice. International Journal for Students as Partners, 1(2), 1-9. https://doi.org/10.15173/ijsap.v1i2.3315 
Matthews, K. E. (2018). Engaging students as participants and partners: An argument for partnership with students in higher education research on student success. International Journal of Chinese Education, 7(1), 42-64. https://doi.org/10.1163/22125868-12340089

Matthews, K. E., Cook-Sather, A., \& Healey, M. (2018). Connecting learning, teaching, and research through student-staff partnerships: Toward universities as egalitarian learning communities. In V. C. H. Tong, A. Standen, \& M. Sotiriou (Eds.), Research equals teaching: Inspiring research-based education through student-staff partnerships (pp. 23-29). London: University College of London Press. Retrieved from http://www.ucl.ac.uk/ucl-press/browse-books/shaping-higher-education-with$\underline{\text { students }}$

Matthews, K. E., Dwyer, A., Hine, L., \& Turner, J. (2018). Conceptions of students as partners. Higher Education, 76(6), 957-971. https://doi.org/10.1007/s10734-018$\underline{0257-y}$

Matthews, K. E., Dwyer, A., Russell, S., \& Enright, E. (2018). It is a complicated thing: Leaders' conceptions of students as partners in the neoliberal university. Studies in Higher Education, 1-12. https://doi.org/10.1080/03075079.2018.1482268

Matthews, K., Groenendijk, L., \& Chunduri, P. (2017). We want to be more involved: Student perceptions of students as partners across the degree program curriculum. International Journal for Students as Partners, 1(2). https://doi.org/10.15173/ijsap.v1i2.3063

Matthews, K. E., Mercer-Mapstone, L., Dvorakova, S. L., Acia, A., Cook-Sather, A., Felten, P., Healey, M., Healey, R., \& Marquis, E. (in press). Enhancing outcomes and reducing inhibitors to the engagement of students and staff in learning and teaching partnerships: Implications for academic development. International Journal for Academic Development.

McMillan, J. J., \& Cheney, G. (1996). The student as consumer: The implications and limitations of a metaphor. Communication Education, 45(1), 1-15. https://doi.org/10.1080/03634529609379028

McPherson, N., \& Heggie, G. (2015). Transitioning to students as partners, producers, collaborators and co-creators. Are we serious? Enhancement and Innovation in Higher Education. Glasgow: QAA Enhancement Themes.

Mercer-Mapstone, L., Dvorakova, S., Matthews, K. E., Abbot, S., Cheng, B., Felten, P., Knorr, K., Marquis, E., Shammas, R., \& Swaim, K. (2017). A systematic literature review of students as partners in higher education. International Journal for Students as Partners, 1(1). https://doi.org/10.15173/ijsap.v1i1.3119

Ntem, A., \& Cook-Sather, A. (2018). Resistances and resiliencies in student-faculty pedagogical partnership. International Journal for Students as Partners, 2(1), 8296. https://doi.org/10.15173/ijsap.v2i1.3372

Quality Assurance Agency (QAA). (2012). UK quality code for higher education. Retrieved from: http://www.qaa.ac.uk/docs/qaa/quality-code/chapter-b5 -studentengagement.pdf?sfvrsn=cd01f781 8

Ratcliffe, M. (2007). Values in the science classroom - the enacted curriculum. In D. Corrigan, J. Dillon, \& R. Gunstone (Eds.), The re-emergence of values in science education (pp. 119132). Rotterdam, The Netherlands: Sense Publishers. 
Ratcliffe, M., Harris, R., \& McWhirter, J. (2004). Teaching ethical aspects of science - is cross-curricular collaboration the answer? School Science Review, 86(315), 39-44.

Tarrant, M., Dazeley, S., \& Cottom, T. (2009). Social categorization and empathy for outgroup members. British Journal of Social Psychology, 48(3), 427-446. https://doi.org/10.1348/014466608×373589

Trowler, P., \& Cooper, A. (2002). Teaching and learning regimes: Implicit theories and recurrent practices in the enhancement of teaching and learning through educational development programmes. Higher Education Research \& Development, 21(3), 221240. https://doi.org/10.1080/0729436022000020742

van Kleef, G. A., Oveis, C., van der Löwe, I., Luokogan, A., Goetz, J., \& Keltner, D. (2008). Power, distress, and compassion: Turning a blind eye to the suffering of others. Psychological Science, 19(12), 1315-1322. https://doi.org/10.1111/j.14679280.2008.02241.x

Wellcome Trust. (2001). Valuable lessons: Engaging with the social context of science in schools. Retrieved from https://wellcome.ac.uk/sites/default/files/wtd003446 0.pdf

Witz, K. (1996). Science with values and values for science education. Journal of Curriculum Studies, 28(5), 597-612.

Yaakobi, D., \& Sharan, S. (1985). Teacher beliefs and practices: The discipline carries the message. Journal of Education for Teaching, 11(2), 187-199.

https://doi.org/10.1080/0260747850110207 